\title{
COMPETITIVENESS AND ITS IMPORTANCE IN MODERN WORLD ECONOMIC PROCESSES
}

\section{Tsalan M. I.}

\section{INTRODUCTION}

The processes taking place nowadays in the world and national economies necessitate a review of the mechanisms and approaches to managing and regulating particular activities. It is important to take into account such challenges in the context of reforming the main lines of business. Nowadays the principles of work and cooperation between countries, regions, enterprises are changing. This must be taken into account while developing long-term development strategies. New trends in the national and international economic environments place new requirements for reorientation of activities and implementation of measures system for timely adaptation to these changes before subjects of different levels and nature, including enterprises of different ownership, particularly state-owned ones. While private enterprises carry out these activities faster, focusing on their own vision, market research and their own capabilities, state-owned enterprises are often forced to comply with government regulation and state support measures. Kyrylov Yu.Ye. emphasizes that in the context of globalization, a new paradigm of competitive development is being formed, when every economic entity of different level and sphere of activity should focus on its level of development and competitiveness ${ }^{1}$. Over time, this issue will become more urgent, for this reason, mechanisms for reorientation of forms of economic activity to the principles of competitive development should be urgently formed.

${ }^{1}$ Кирилов Ю.С. Конкурентоспроможний розвиток аграрного сектору економіки України в умовах глобалізації: теорія, методологія, практика : дис. ... д-ра екон. наук : 08.00.03. Херсон, 2015. 


\section{Competitiveness as a basis for competitive development ensuring}

According to M.A. Khvesyk and A.M. Sunduk, the competitive development of the economy is the process of improving its quantitative and qualitative characteristics. Such a process takes into account the constancy of functioning, the characteristics of which are conditioned by the influence of a complex of socio-economic and other factors of endoand exogenous orientation ${ }^{2}$. The basis of competitive development is the economic category of competitiveness. In general, it is important to note that competitiveness is studied and determined not only at the level of the national economy, but also at the level of regions, industries, enterprises and goods. This concept is studied in a broad and narrow sense. In a broad sense, competitiveness is the presence of strong, stable positions in the market ${ }^{3}$. According to the definition of the Organization for Economic Cooperation and Development, competitiveness should be understood as the ability of companies, industries, regions and nations to generate high levels of income and remuneration, while remaining open to international competition ${ }^{1}$.

L. Kyrylenko points out that competitiveness is especially relevant in the conditions of a market economic system. This is an important socio-economic category of a market economy, which reflects the universal properties and relations of market interaction of economic entities and patterns of a market organization of economic activity development in general ${ }^{4}$.

S. Mochernyi, T. Siudek, A. Zavojska, and others formulated their views on competitiveness through the prism of market and market relations. Competitiveness as "the ability to act in the conditions of market relations and at the same time to obtain a profit sufficient for scientific and technological improvement of production, stimulation of employees and support of products at a high quality level" defines

${ }^{2}$ Хвесик М.А., Сундук, А.М. Управління розвитком національної економіки в контексті дії глобальних процесів. Економіка України. 2013. № 3. С. 4-16.

${ }^{3}$ Румянцева Е.Е. Новая экономическая энциклопедия. Москва, 2005. С. 218.

${ }^{4}$ Кириленко Л. Конкурентоспроможність як категорія ринкової економіки. Вісник Київського наиіонального університету. 2011. № 124-125. С. 49-52. 
S.V. Mochernyj ${ }^{5}$. In another scientific work competitiveness is also considered in market conditions ${ }^{6}$. On the other hand, competitiveness is the property of a product, a service, a subject of market relations to act on the market on an equal footing with similar goods, services or competing subjects of market relations ${ }^{7}$. In view of the above definitions, it is possible to make such generalizations that competitiveness is the ability to withstand competition in the market and to generate profit that enables an entity to develop.

In the study of competitiveness V.L. Korinev and R.I. Zhovnovach distinguish macro-level (country competitiveness), mezzanine (regional and industry competitiveness) and micro-level (enterprise and product competitiveness $)^{8}$. The levels of competitiveness research are shown in Figure 1.

Today, another level of competitiveness, namely the nanolevel, is a relatively new approach. N.M. Kuprina adds the nanoscales to the overall structuring, where they consider the competitiveness of the products of a private entrepreneur (individual) and the level of the cluster structures competitiveness as an intermediate level between the level of the enterprise competitiveness and the level of industry and region competitiveness ${ }^{9}$. In recent years, the cluster organization of activities ${ }^{10}$ has become increasingly important in the economy, and therefore we fully support the need to expand the scope of scientific research on the competitiveness of clusters as subjects of economic activity, as well as

${ }^{5}$ Мочерний С.В. Економічний словник-довідник / ред. С.В. Мочерний. Київ, 1995. C. 164.

${ }^{6}$ Siudek T., Zavojska A. Competitiveness in the economic concepts, theories and empirical research. ACTA Scientiarum polonorum. 2014. № 13 (1). P. 91-108.

${ }^{7}$ Абалкин Л.И. Экономическая энциклопедия. / ред. Л.И. Абалкин. Москва, 1999.

${ }^{8}$ Корінєв В.Л., Жовновач Р.І. Оцінювання конкурентоспроможності об'єктів і суб'єктів господарювання. Вісник Запорізького начіонального університету: Збірн. наук. праць. Економічні науки, 2011. № 2 (10). С. 45-52.

${ }^{9}$ Куприна Н.М. Конкурентоспособность деятельности предприятия: виды и уровень. Формування ринкової економіки: зб. наук. праць. - Спец. вип. Регіональний розвиток Украӥни: проблеми та перспективи: у 2-х ч. 2011. (Ч. 1). Київ.

${ }^{10}$ Tiits M. Competitiveness of Estonian forest and wood cluster / Ed. Tiits M. URL: https://www.ibs.ee/en/publications/competitiveness-of-estonian-forest-wood-cluster/ 
instruments of competitive development of industries, regions and countries.

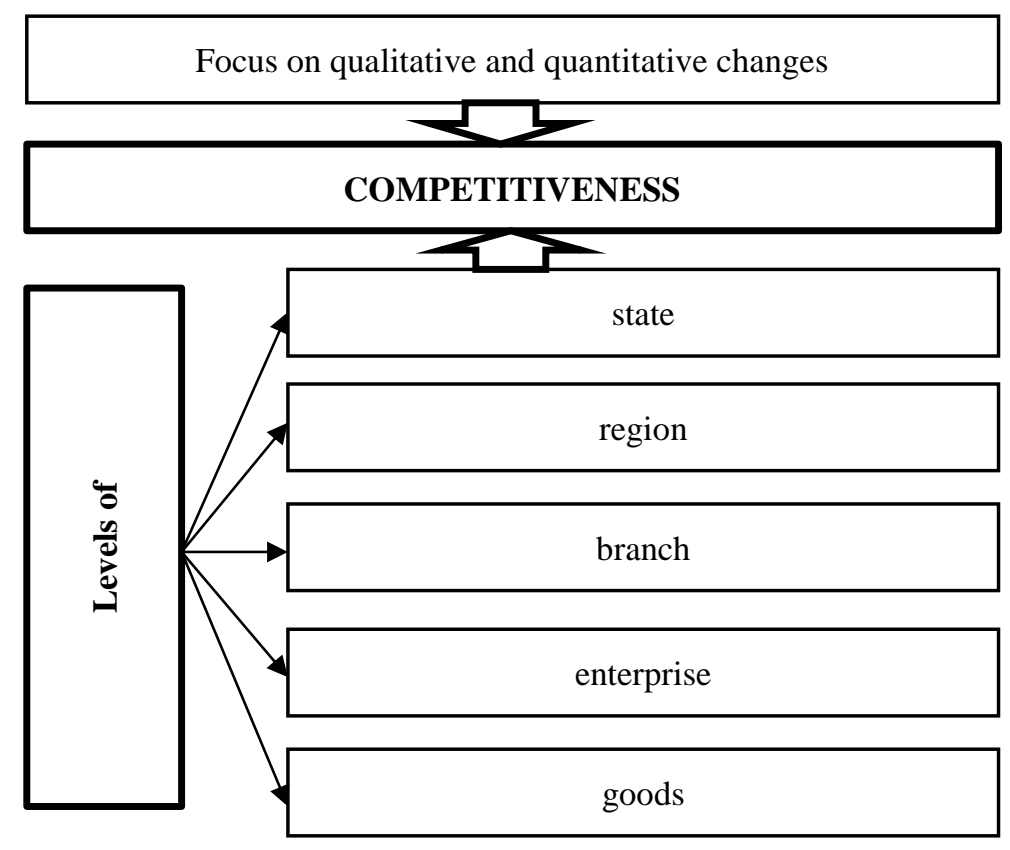

Figure 1. Levels of research and study of the "competitiveness" concept

V. Andrianov notes that there is a correlation between all levels, because the competitiveness of the country and the industry depends on the ability of competitive manufacturers to produce competitive goods ${ }^{11}$. B.M. Kurganskaya emphasizes the connection between the concepts of product competitiveness and the enterprise competitiveness ${ }^{12}$. Scientists

${ }^{11}$ Андріанов В.Д. Конкурентоспроможність Росії у світовій економіці. Світова економіка та міжнародні відносини, 2000. № 3. С. 47-57.

${ }^{12}$ Курганська Б. М. Організаційно-економічні механізми забезпечення конкурентоздатності підприємства (на прикладі швейної промисловості) : дис. ... канд. екон. наук : 08.06.01. Львів, 2002. 
in their theory of mezzanine levels proceed from the definition of the middle link, which, without losing the signs of the original object, at the same time acquires the signs of the next link, which gives it additional socio-organizational energy. Based on this hypothesis, they proved that the intermediate level, located at the boundary of the micro- and macroenvironment, accumulates the advantages of both the lower and upper levels ${ }^{13}$. P.R. Putsentejllo emphasizes on the synergistic effect, assuming that the competitive advantages of the industry as a subject of mezzanine level do not only combine the strengths of firms and the external macroeconomic environment, but also enhance them ${ }^{14}$. On this basis, we believe that the competitive development of economic activity in the region will depend on the competitive development of enterprises in a particular industry and will be one of the components of the region economy competitiveness as a whole.

Competitiveness is a complex phenomenon that has its own specific meaning depending on the level at which it is examined and investigated. In addition, it should be noted that the interconnectedness of levels is due to the fact that each lower level is a component of a higher level. Therefore, we have reason to argue that providing competitiveness at the lower level contributes in part to the competitiveness at the higher level. Competitive enterprises are contributing to the competitiveness of the region, and in turn, to the competitiveness of the country. Therefore, in order to reach the maximum level of competitiveness of the country, it is necessary to maximize the efforts of increasing the competitiveness at all previous levels.

\section{Factors of competitive development in the regional dimension}

Today, along with globalization processes, processes of regionalization are being actively pursued, which is often seen as a stage

13 Демченко А. А., Кузбожьев Э. Н. Управление конкурентоспособностью предприятий отраслевого комплекса: моногр. Курск, 2002.

${ }^{14}$ Пуцентейло П. Р. Конкурентоспроможний розвиток галузі тваринництва як найвищий рівень прояву конкуренції. Інноваційна економіка, 2014. № 3. С. 55-61. 
and response to globalization processes $^{15}$. Kurakov V. defines regionalization as the development, strengthening of economic, political and other ties between regions or states within one region; the emergence of regional associations of states ${ }^{16}$.

This approach points to the multifaceted notion of "region", which may encompass the administrative units of an individual country, country by itself, or the totality thereof. In view of this and the diversification of ties configuration between regions in modern international relations, increasing attention was paid to the competitive development ensuring of the regions themselves. When the processes of powers decentralization, and the levers of management and development are transferred to the regional level, the subjects of economic activity of a particular region should take care of their current economic problems and prospects.

In today's environment, only competitive entities can provide active management in the region, thereby maintaining their competitive position in the market and improving the position of the region and the country as a whole. Each region, on the basis of natural, economic and other advantages, has priority types of economic activity, at the expense of which it can increase the level of its development. Within one work, it is difficult to consider several sectors of the economy and the factors that determine competitiveness at the regional level. For example, we have selected the forestry sector, which is of strategic importance both in the European Union and in Ukraine, according to the economic, environmental and social components of its development.Forests are an important part of the national wealth of states and regions. It is a favorable ecological, healthy environment of human activity and a source of raw materials for economic development. By-products are valuable both for meeting human needs (nutrition, treatment), and for supporting production processes (food, medicine, etc.).

15 Дергачев В.А. Геоэкономический словарь-справочник. Одесса, 2004. - URL: http://politike.ru/dictionary/973

16 Экономика и право: словарь-справочник / Л.П. Кураков, В.Л. Кураков, А.Л. Кураков. Москва, 2004. 1288 с. - URL: http://www.twirpx.com/file/1539752 
The competitive development of forestry is influenced by a number of general and special factors. Factor is the driving force or condition of any process or phenomenon. D.A. Panasenko defines a factor as the set of conditions by which one or another process is carried out, one result or another is ensured ${ }^{17}$. Factors often mean the parameters, the nature and effectiveness of economic processes depends on, and which determine the quantity and quality of the manufactured economic product $^{18}$.

Scientists separately define the concept of competitive factors. In this regard, S.M. Bondarenko and V.I. Bokiy argue that competitive factors are the driving force that shapes and determines the nature of competitiveness $^{19}$. L.A. Zaytseva summarizes that the competitive factor is the driving force acquired in the effective economic processes, which allows to stand in competition ${ }^{20}$.

The basis of forest management is the activity of forestry enterprises, therefore, among the factors of competitive development of the forest industry factors of enterprises competitiveness should be considered.

As A. Marenych and I. Astakhov point out, competitiveness as a complex characteristic of the activity of enterprises is based on the analysis of various aspects of production and economic activity (production potential, labor resources, availability of materials, financial results of activities, etc.), and allows to identify companies strengths in competition, find ways to achieve an advantage over competitors ${ }^{21}$.

${ }^{17}$ Панасенко Д. А. Системний підхід до показників конкурентоспроможності. Формування ринкових відносин в Україні, 2008. № 3(82). С. 19-24.

18 Жовновач Р. І. Системний підхід до управління конкурентоспроможністю підприємства. - URL : www.nbuv.gov.ua/portal/natural/npkntu_e/2010_18_1/stat.../50.pdf.

19 Бондаренко С. М., Бокій В. І. Про механізм формування конкурентоспроможності продукції промислового підприємства. Економіст, 2001. № 9. С. 58-59.

20 Зайцева Л. О. Класифікація факторів конкурентоспроможності підприємства. URL: http://dspace.luguniv.edu.ua/jspui/bitstream/123456789/525/1/zaitseva\%201\%2012\%20 052012.pdf

${ }^{21}$ Маренич А., Астахова И. Управление конкурентоспособностью предприятия. Бизнес-Информ, 1996. № 5. С. 23-27. 
Scientists often include the factors of the internal economy organization, as well as those formed in the external environment of their activity, as components of the analysis of enterprises competitive development. A.H. Bydyk, believes that the competitiveness of an enterprise is determined by the resource potential, the results of economic activity, the financial and economic state of enterprises ${ }^{22}$. On the other hand, competitiveness depends on the market in which the company operates. D.V. Malashchuk believes that in order to compete successfully in the domestic and foreign markets, businesses need to have such "competitive arguments" as: tax legislation aimed at stimulating business activity, production productivity, reducing capital cost, developing productive forces, infrastructure, technical and technological instruments, business information support and other means of exporter support ${ }^{23}$.

From the above competitive advantages it is evident that D.V. Malashchuk includes to them both those which depend on the enterprise itself, and those which depend on the environment in which the enterprises operate. The degree of influence of the environment on the internal organization of the enterprise depends on the functioning of the market, which in turn depends on the well-being of consumers and their solvency, i.e. demand, market capacity, including the scientific and technological achievements, which contribute to diversification of commodity positions and growth offers in terms of quantity and quality, as well as the creation of an appropriate entrepreneurial environment in the region and the country as a whole (opportunities to enter the market, favorable conditions for starting own business, tax policy and others). The influence of the external environment is determined by the potential of the internal organization of work of the business structure to withstand this influence, which is governed by the leadership and management qualification, financial potential of the entity, opportunities for

22 Бидик А.Г. Підвищення конкурентоспроможності аграрного виробництва. Економіка АПК, 2003. № 6. С. 115-121.

${ }^{23}$ Малащук Д.В. Пріоритетні заходи щодо забезпечення конкурентоспроможності економіки України. Актуальні проблеми економіки, 2005. № 1 (43). С. 22-31. 
innovation (Innovation is represented as the ability to update itself, as internal organizational processes of restructuring by the criteria: rhythm, adaptability, minimal cost $)^{24}$, the effectiveness of the strategic vision of economic development in perspective. According to Yu.F. Yaroshenko, the system of the enterprise competitiveness increasing should include a subsystem providing adaptation to environmental conditions, which is expressed in such concept as adaptability (Adaptability of the organization is the property of adaptation, a form of relations between the enterprise and the external environment, as a process of organizational restructuring $)^{25}$, the subsystem of providing flexibility of management structure and production system, subsystem of ensuring of the effective enterprise and the market potential utilization, which are interdependent and at the same time are relatively autonomous. Therefore, the better the internal environment of the enterprise is organized, the easier it adapts to the "challenges" of the external environment and functions more successfully.

The criteria for competitive development are also determined in the world practice, focusing more on the external environment, and they include the enhancement of technological advantages, the increase of innovative advantages, the development of benefits under the influence of globalization.

Summarizing the different approaches, it should be noted that the opinions of scientists are divided: some emphasize on the provision of resources, the level of the production process cost, the organization of the business structure activity and its management, others - on the environment in which the enterprise operates. We have summarized the views of scientists in the competitive development of enterprises researching and ensuring in Figure 2.

24 Хамазіна Т.О. Розвиток підприємницької організації в конкурентному середовищі. Держсава та регіони. Серія: Економіка та підприємництво, 2005. № 1. C. 305-311; c. 306-307.

25 Ярошенко Ю.Ф. Формування організаційно-економічного механізму підвищення конкурентоспроможності підприємства : автореф. дис. ... канд.екон.наук : 08.06.01. Харків, 2001. 19 с. 


\section{COMPETITIVE DEVELOPMENT OF ENTERPRISES}

\begin{tabular}{|c|c|}
\hline External factors & Internal factors \\
\hline$]^{2}$ & J \\
\hline Globalization processes & $\begin{array}{l}\text { Resource security (access to } \\
\text { technological, financial, } \\
\text { labor, logistical resources) }\end{array}$ \\
\hline $\begin{array}{l}\text { Legislative support } \\
\text { Conditions of competition }\end{array}$ & $\begin{array}{c}\text { Organizational (optimized } \\
\text { work of the enterprise } \\
\text { ensuring) }\end{array}$ \\
\hline State support & $\begin{array}{l}\text { Management (professional } \\
\text { management and control of } \\
\text { the enterprise) }\end{array}$ \\
\hline
\end{tabular}

Figure 2. Factors for the competitive development of enterprises ensuring

Competitiveness factors shown in Figure 2 are common to different sectors of the economy, while in the forest industry, competitive enterprise development should be adjusted to the rational use of forest resources, taking into account the conservation and restoration conditions of the forest fund of the region and the country as a whole.

T.I. Posvyatenko notes that at the enterprise level the following factors contribute to competitive development ensuring:

- resource factor (physical consumption of resources per unit of finished product - feedback from partial and overall performance indicators);

- price factor (level and dynamics of prices for all used production resources and finished products); 
- "environmental factor" (economic policy of the state and the level of its influence on the market counterparty $)^{26}$.

The factors influencing the competitiveness of an enterprise research makes possible to determine which of them increase it. Arthur A. Thompson, Jr. and A. Strickland among "factors of the company success", focusing on the internal component, determine the following: quality and characteristics of products, reputation (image), production capacity, use of technology, dealer network and distribution opportunities, innovative capabilities, financial resources, costs compared to competitors, customer service ${ }^{27}$.

The classification of the factors influencing the competitiveness of enterprises is also made by B.M. Kurganska. By the scope she divides them into internal and external, by the form of influence - direct and indirect, by the nature of the action - on economic, political, organizational etc. $^{12}$

Under the factor of enterprise competitiveness M.M. Halelyuk offers to understand the factors of the internal and external environment of an enterprise that affect its ability to increase competitiveness in a particular market ${ }^{28}$. He classifies them according to different classification characteristics, namely: the level of influence (microeconomic, macroeconomic), the nature of manifestation (explicit, hidden), the possibility of prediction (random, regular), the nature of influence (negative, positive, neutral), the possibility of measuring impact (non-measuring, low-measuring, measuring), dynamic of action (static, dynamic), period of influence (discrete, continuous), degree of complexity (single, complex), scale of distribution (general, specific), controllability (managed, poorly managed, unmanaged). According to the medium of influence M.M. Halelyuk distinguishes internal and

${ }^{26}$ Посвятенко Т.I. Фактори конкурентоспроможності суб'єктів на товарних ринках. Держава та регіони. Серія: Економіка та підприємництво, 2005. № 4. C. 202-206.

27 Томпсон-мл. Артур А., Стрикленд, А.Дж. Стратегический менеджмент: концепции и ситуации для анализа / 12-е изд., пер. с англ. Москва, 2003. 928 с.

${ }^{28}$ Галелюк М.М. Чинники та стратегії конкурентосрможності машинобудівних підприємств : автореф. дис. ... канд.екон.наук : 08.00.04. Львів, 2010. 28 с. 
external factors of enterprise competitiveness. External factors are important, but internal factors should not be overlooked. Even the most favorable external factors will not be able to provide highly efficient development, if ineffective internal organization of activity takes place. M.M. Haleluk divides external factors into two groups according to the direction of their action, namely, direct and indirect factors ${ }^{28}$. The factors of direct action include the level of competition in the industry, the capacity of the main competitors, the level and peculiarities of demand, the availability and competitiveness of suppliers, availability of resources, legal regulations in the country. Indirect factors include climatic conditions, geographical location of the country, regions, tax and interest rates in the country, socio-cultural, demographic circumstances, national standardization and certification system, state support for business, peculiarities of economic management of the country, industry, region, political events in the country, openness of society and markets, quality of information support, level of integration in the country and within the world community.

V. Martsyn as external factors determines ones that company can not change and should perceive them as something invariable ${ }^{29}$. In other words, these are the factors that an enterprise needs to adapt to its operations, optimizing costs and benefits, maximizing its competitive advantage in these circumstances. According to V. Martsyn, external factors include the following:

- activity of state power structures (fiscal and monetary policy, legislation);

- economic conjuncture. It includes the conjuncture of commodity and material markets, labor markets, means of production markets, financial resources markets;

- development of the main supporting industries (development of new technologies (resource-saving, deep processing technologies), new

${ }^{29}$ Марцин В. Умови виникнення та показники оцінки факторів, що формують конкурентоспроможність підприємства. - URL: http://www.anvou.org.ua/academy/herald_info/ visnyk_61_5_08/visnyk_61_5_08_98-113.pdf. 
materials and energy sources, their introduction into production increases the scientific and production potential of the enterprise);

- demand parameters (growth of demand for goods produced by the enterprise, its stability, consolidation of market position $)^{29}$.

In our opinion, the division of factors that influence the activity of the enterprise and its competitive development into external and internal is debatable. On the one hand, there are internal factors that determine the internal organization of the enterprise, and external factors that affect its operation from the outside. And from the point of view of foreign economic activity conducting by the enterprise, external ones may be those acting on the foreign market in relation to the national market, and internal ones may be those factors that take place directly in the national market in which the enterprise operates.

Thus, when analyzing export-oriented enterprises, external factors that affect the export activity of enterprises in the conquest of global industry markets are often identified. These are: the dependence on the global market conditions, aggressive competition policy, limited demand for products, insufficient solvency of key consumers from underdeveloped countries, and the global economic crisis. Internal factors, according to N.O. Filipova, are: insufficient budget financing, bureaucratic system of export control, depreciation of fixed assets, poor legal regulation, rigid tax policy, outflow and aging of personnel, lack of state support, a small share of closed-loop production ${ }^{30}$.

It is important to note that the factors are general (which affect all components of the enterprise's operating environment) and specific (which affect the competitive environment of a particular industry or region). Given the limited coverage of factors affecting forestry activity in the literature, we consider it appropriate to divide them into state-level and regional-level influence factors. The first should include the following:

30 Філіпова, Н.О. Розвиток експортної діяльності високотехнологічних підприємств в умовах загострення конкуренції : автореф. дис. ... канд.екон.наук : 08.00.04. Запоріжжя, 2008. 20 c. 
- legislative - creation of a legislative framework that forms the conditions and regulates the implementation of forestry activities;

- economic - the economic situation in the state directly affects the implementation of commercial activities in general and forestry in particular;

- political - in the aspect of forest policy, taking liberalization or protectionist measures to develop forestry activities;

- institutional - creation of institutional support for the implementation of forestry activities;

- demographic - demographic situation in the countries and regions is a factor affecting the consumption of timber and by-products and to a lesser extent the employment in forestry;

- technical and technological factor - the level of development of this sphere in the state influences the technical and technological support of the branches of economy;

- socio-cultural factor - understanding of the role of forestry from the economic, ecological and social point of view in terms of cultural, mental and regional characteristics of the population and their willingness to participate in the conservation of the forest as a natural wealth.

This list of factors is suggested to be complemented by other factors affecting forestry and emerging at the regional level, namely:

- structure of the regional economy - the share of the industry in the regional economic system creates the preconditions for its development;

- historical - is a factor formed during the period of development of the industry and determines its peculiarities in the region;

- environmental - these are the components of the environment that determine the development of forestry in the region;

- geographical - location of the region influences the formation of economic relations in forest industry with foreign partners;

- logistic - promotes the formation of communication channels between forestry entities within the region and country; 
- clustering factor - a factor of competitive development of forestry in the region through the creation of forestry clusters.

Specific factors determining the development of forestry include:

- natural factor, which presupposes the location of forest resources in the territory, dependence on which determines the length of the production of wood period, and the production itself requires a specific material and technical base;

- technical and technological factor, world and national level of development of wood processing technologies;

- human factor that determines the specific conditions of life and development of the rural population, which is the main provider of labor resources for forestry ${ }^{31}$.

The natural factor is of particular importance in forestry, which contains both the provision of forest resources in a whole and the type of dominant breed in the forest fund of the enterprise. That is, forestry, which is in an area with large reserves of forest resources that are of higher quality and value, will have better starting conditions for ensuring its competitive development. Although the availability of resources alone does not ensure the high efficiency of the enterprise activity.

If the company wants to support its development and reach the expansion of markets, it must, according to H.M. Skudar, constantly take care to add to the set of activities new ones and to stop in time those which no longer meet the strategic goals and new orientations ${ }^{32}$. Similarly, when it comes to the factors of competitiveness of an enterprise, it is necessary to focus on those that increase it and level out those that reduce. Indeed, factors can be both positive and a negative, that is, a risk effect that is specific for the forest industry and especially manifested in it, as negative processes of a natural character (winds, forest fires, illegal deforestation, which result as natural losses and

${ }^{31}$ Овчарук В. В. Аналіз конкурентоспроможності лісогосподарських підприємств Хмельницької області. Науковий вісник НЛТУ Украӥни, 2008. № 18.9. С. 239-243.

${ }^{32}$ Скудар Г.М. Організаційно-економічний механізм управління конкурентоспроможністю підприємства : автореф. дис. ... докт.екон.наук : 08.02.03. Донецьк, 2000. $40 \mathrm{c}$. 
economic losses), imperfection of mechanisms of organization of forestry activities, conflicts of interest of socio-economic nature (enterprises seek to maximize their profits, but must act in the conditions of regional forest resources conservation for the benefit of the population). Therefore, forestry should maximize the impact of incentives (those that have a positive impact on the activity of the enterprise) and minimize the effect of disincentives (which impede the process of increasing the competitiveness of the forestry enterprise).

\section{CONCLUSIONS}

In the revitalization period of globalization, regionalization and integration processes, the concept of competitiveness with regard to macro, mezzanine and micro levels of economic entities activity is updated. Competitiveness is an economic category that reflects the subject's ability to compete. Higher levels of competitiveness provide stronger competitive positions in the market in which the business is conducted.

Competitiveness is a multifaceted and hierarchical phenomenon. Competitive entities of one level make a contribution to the competitiveness of another higher level. A feature of the regional dimension of competitiveness is that it depends on the competitiveness of industries, enterprises and goods, and contributes to the level of competitiveness of the country. It is important to investigate the factors that exert their influence at different levels. There are a large number of them. They are divided into several groups just at the regional level in the forestry sector.Among the factors that determine the development of forestry in the context of regional development, it is advisable to consider both factors that affect the competitive development of forestry enterprises, including a group of internal and external factors, and factors affecting forestry in the region formed at the national and regional levels. This approach allows for a comprehensive analysis of the forestry activities development, the identification of complexities and the development of appropriate tools to achieve the goals. 


\section{SUMMARY}

The main theoretical approaches to defining the concept of competitiveness have been considered by the author. Attention has been paid to the importance of this economic category in the current conditions of the world economic environment transformation and the formation of a new paradigm of competitive development. Competitiveness implies the presence of strong, stable positions in the market and should be understood as the ability of a competitive entity to generate profits, maximize them and invest in their future development. The levels of competitiveness research have been analyzed by the author. The role of the region in the modern world economic environment has been considered. The factors of competitive development of enterprises on the example of the forest industry have been defined. The forestry industry has been selected in view of its importance in the context of current areas of ecological, economic and social development.

\section{REFERENCES}

1. Кирилов Ю.С. Конкурентоспроможний розвиток аграрного сектору економіки України в умовах глобалізації: теорія, методологія, практика : дис. ... д-ра екон. наук : 08.00.03. Херсон, 2015.

2. Хвесик М.А., Сундук, А.М. Управління розвитком національної економіки в контексті дії глобальних процесів. Економіка України. 2013. № 3. С. 4-16.

3. Румянцева Е.Е. Новая экономическая энииклопедия. Москва, 2005. С. 218.

4. Кириленко Л. Конкурентоспроможність як категорія ринкової економіки. Вісник Київського наиіонального університету. 2011. № 124-125. С. 49-52.

5. Мочерний С.В. Економічний словник-довідник / ред. С.В. Мочерний. Київ, 1995. С. 164. 
6. Siudek T., Zavojska A. Competitiveness in the economic concepts, theories and empirical research. ACTA Scientiarum polonorum. 2014. № 13 (1). Р. 91-108.

7. Абалкин Л.И. Экономическая энциклопедия. / ред. Л.И. Абалкин. Москва, 1999. С. Экономика.

8. Корінєв В.Л., Жовновач Р.І. Оцінювання конкурентоспроможності об'єктів і суб'єктів господарювання. Вісник Запорізького начіонального університету: Збірн. наук. праџь. Економічні науки, 2011. № 2 (10). С. 45-52.

9. Куприна Н.М. Конкурентоспособность деятельности предприятия: виды и уровень. Формування ринкової економіки: зб. наук. праць. - Спец. вип. Регіональний розвиток Украӥни: проблеми та перспективи: у 2-х ч. 2011. (Ч. 1). Київ.

10. Tiits M. Competitiveness of Estonian forest and wood cluster / Ed. Tiits M. URL: https://www.ibs.ee/en/publications/competitiveness-ofestonian-forest-wood-cluster/ (date of access: 25.12.2019).

11. Андріанов В.Д. Конкурентоспроможність Росії у світовій економіці. Світова економіка та міжнародні відносини, 2000. № 3. C. 47-57.

12. Курганська Б. М. Організаційно-економічні механізми забезпечення конкурентоздатності підприємства (на прикладі швейної промисловості) : дис. ... канд. екон. наук : 08.06.01. Львів, 2002.

13. Демченко А. А., Кузбожьев Э. Н. (2002). Управление конкурентоспособностью предприятий отраслевого комплекса: моногр. Курск, 2002.

14. Пуцентейло П. Р. Конкурентоспроможний розвиток галузі тваринництва як найвищий рівень прояву конкуренції. Інновачійна економіка, 2014. № 3. С. 55-61.

15. Дергачев В.А. Геоэкономический словарь-справочник. Одесса, 2004. - URL: http://politike.ru/dictionary/973 (дата звернення: 15.10.2019). 
16. Экономика и право: словарь-справочник / Л.П. Кураков, В.Л. Кураков, А.Л. Кураков. Москва, 2004. 1288 с. - URL: http://www.twirpx.com/file/1539752_(дата звернення: 07.09.2019).

17. Панасенко Д. А. Системний підхід до показників конкурентоспроможності. Формування ринкових відносин в Украйні, 2008. № 3(82). С. 19-24.

18. Жовновач Р. І. Системний підхід до управління конкурентоспроможністю підприємства. - URL: : www.nbuv.gov.ua/ portal/natural/npkntu_e/2010_18_1/stat.../50.pdf (дата звернення: 27.09.2019).

19. Бондаренко С. М., Бокій В. І. Про механізм формування конкурентоспроможності продукції промислового підприємства. Економіст, 2001. № 9. С. 58-59.

20. Зайцева Л. О. Класифікація факторів конкурентоспроможності підприємства. - URL: http://dspace.luguniv.edu.ua/jspui/ bitstream/123456789/525/1/zaitseva\%201\%2012\%20052012.pdf (дата звернення: 21.10.2019).

21. Маренич А., Астахова И. Управление конкурентоспособностью предприятия. Бизнес-Информ, 1996. № 5. С. 23-27.

22. Бидик А.Г. Підвищення конкурентоспроможності аграрного виробництва. Економіка АПК, 2003. № 6. С. 115-121.

23. Малащук Д.В. Пріоритетні заходи щодо забезпечення конкурентоспроможності економіки України. Актуальні проблеми економіки, 2005. № 1 (43). С. 22-31.

24. Хамазіна Т.О. Розвиток підприємницької організації в конкурентному середовищі. Держава та регіони. Серія: Економіка та підприємництво, 2005. № 1. С. 305-311.

25. Ярошенко Ю.Ф. Формування організаційно-економічного механізму підвищення конкурентоспроможності підприємства : автореф. дис. ... канд.екон.наук : 08.06.01. Харків, 2001. 19 с.

26. Посвятенко T.I. Фактори конкурентоспроможності суб'єктів на товарних ринках. Держава та регіони. Серія: Економіка та підприємниитво, 2005. № 4. С. 202-206. 
27. Томпсон-мл. Артур А., Стрикленд, А.Дж. Стратегический менеджмент: концепции и ситуации для анализа / 12-е изд., пер. с англ. Москва, 2003. 928 с.

28. Галелюк М.М. Чинники та стратегії конкурентосрможності машинобудівних підприємств : автореф. дис. ... канд.екон.наук : 08.00.04. Львів, 2010. 28 с.

29. Марцин В. Умови виникнення та показники оцінки факторів, що формують конкурентоспроможність підприємства. URL: http://www.anvou.org.ua/academy/herald_info/visnyk_61_5_08/ visnyk_61_5_08_98-113.pdf (дата звернення: 09.12.2019)

30. Філіпова Н.О. Розвиток експортної діяльності високотехнологічних підприємств в умовах загострення конкуренції : автореф. дис. ... канд.екон.наук : 08.00.04. Запоріжжя, 2008. 20 с.

31. Овчарук В. В. Аналіз конкурентоспроможності лісогосподарських підприємств Хмельницької області. Науковий вісник НЛТУ України, 2008. № 18.9. С. 239-243.

32. Скудар Г.М. Організаційно-економічний механізм управління конкурентоспроможністю підприємства : автореф. дис. ... докт.екон.наук : 08.02.03. Донецьк, 2000. 40 с.

\section{Information about the author:} Tsalan M. I., Candidate of Economic Sciences, Associate Professor, Uzhhorod National University 14, Universytetska str, Uzhhorod, 88000, Ukraine 